\title{
Simple primary $\beta$-amino alcohol catalyzed enantioselective Diels-Alder reaction of 3-hydroxy-2-pyridones
}

Toshihisa Takahashi, ${ }^{a}$ U. V. Subba Reddy, ${ }^{a}$ Yoshihito Kohari, ${ }^{a}$ Chigusa Seki, ${ }^{\text {a }}$ Taniyuki Furuyama, ${ }^{\mathrm{b}}$ Nagao Kobayashi, ${ }^{\mathrm{c}}$ Yuko Okuyama, ${ }^{\mathrm{d}}$ Eunsang Kwon, ${ }^{\mathrm{e}}$ Koji Uwai, ${ }^{\mathrm{a}}$ Michio Tokiwa, ${ }^{\mathrm{f}}$ Mitsuhiro Takeshita ${ }^{\mathrm{f}}$ and Hiroto Nakano ${ }^{\mathrm{a}^{*}}$

\footnotetext{
${ }^{a}$ Division of Sustainable and Environmental Engineering, Graduate School of Engineering, Muroran Institute of Technology, 27-1 Mizumoto, Muroran 0508585, Japan

${ }^{b}$ Graduate School of Natural Science and Technology, Kanazawa University, Kakuma-machi, Kanazawa, 920-1192, Japan

${ }^{c}$ Faculty of Textile Science and Technology, Shinshu University, Ueda, 386-8567, Japan

${ }^{d}$ Tohoku Medical and Pharmaceutical University, 4-4-1 Komatsushima, Aoba-ku, Sendai 981-8558, Japan

Research and Analytical Center for Giant Molecules, Graduate School of Sciences, Tohoku University, 6-3 Aoba, Aramaki, Aoba-ku, Sendai 980-8578, Japan

${ }^{f}$ Tokiwakai Group, 62 Numajiri Tsuduri-chou Uchigo Iwaki 973-8053, Japan
}

\section{ARTICLE INFO}

\section{Article history:}

Received

Received in revised form

Accepted

Available online

\section{Keywords:}

Primary $\beta$-amino alcohol

Diels-Alder reaction

3-hydroxy-2-pyridone

Enantioselective organocatalysis

\section{ABSTRACT}

The simple primary $\beta$-amino alcohol catalyzed Diels-Alder reaction of 3-hydroxy-2-pyridones as dienes with $N$-substituted maleimides to provide the highly substituted optically active isoquinuclidines as a single diastereomers in excellent enantioselectivities (up to $98 \%$ ) with excellent chemical yields (up to $95 \%$ ) was demonstrated. A range of simple $\beta$-amino alcohols were synthesized from the corresponding inexpensive amino acids and their catalytic activity was examined for this reaction.

2009 Elsevier Ltd. All rights reserved.

\section{Introduction}

From the last 15 years, enantioselective organocatalysis is emerging as one of the most powerful synthetic paradigm and also as complementary to metal-catalyzed transformations to accelerated the development of new methods to construction of biologically active complex natural products. ${ }^{1}$ It is always challenging task for synthetic organic chemists to develop the general method for the enantioselective synthesis of complex natural products. The Diels-Alder (DA) reaction is one of the most important and powerful method as it could provide carbocyclic compounds containing up to four contiguous stereo genic centers in a single step. ${ }^{2,3}$ Usually, chiral Lewis acids are effective in enantioselective Diels-Alder reaction to produce the chiral building blocks. ${ }^{4}$ Recently, the use of optically active organic Brønsted acids or Brønsted bases have also emerged as an effective alternative catalysts for catalytic asymmetric DA reactions. ${ }^{5}$ The DA reaction of 3-hydroxy-2-pyridones as diene provides a direct and versatile access to synthetically valuable multifunctional bicyclic optically active isoquinuclidines containing hydroxyl group at 4-position (4-hydroxy-2azabicyclo[2.2.2] octanes), which are valuable synthetic intermediates of biologically active validamines ${ }^{6}$ and pharmacologically important compounds such as oseltamivir phosphate (Tamiflu) ${ }^{7}$ (Scheme 1).

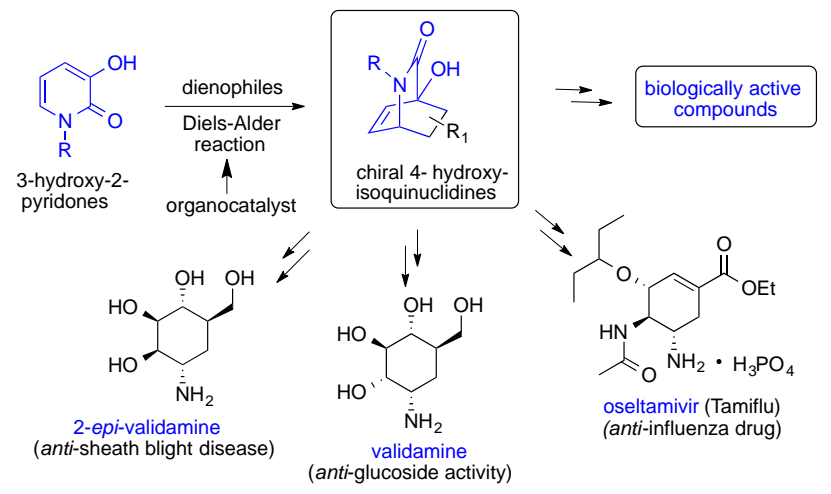

Scheme 1. Efficacy of asymmetric Diels-Alder reaction of 3hydroxy-2-pyridones.

However, as electron-deficient dienes of aromatic character, 3-hydroxy-2-pyridones are known to be reluctant diene partners for DA reactions. Because of this distinct character of 3-hydroxy-

* Corresponding author. Tel.: +81 14346 5727; e-mail: catanaka@mmm.muroran-it.ac.jp (H. Nakano) 
2-pyridones, it is challenge for the development of a catalytic asymmetric variant for this synthetically useful class of DA reactions. To the best of our knowledge, till the date there are only few reports for racemic version of this class of DA reaction using 3-hydroxy-2-pyridones as dienes ${ }^{8}$ and only one example for catalytic asymmetric version of this DA reaction reported by Tan and co-workers using indanol-typed tertiary amino alcohol as a Brønsted base organocatalyst (Scheme 2). ${ }^{9}$

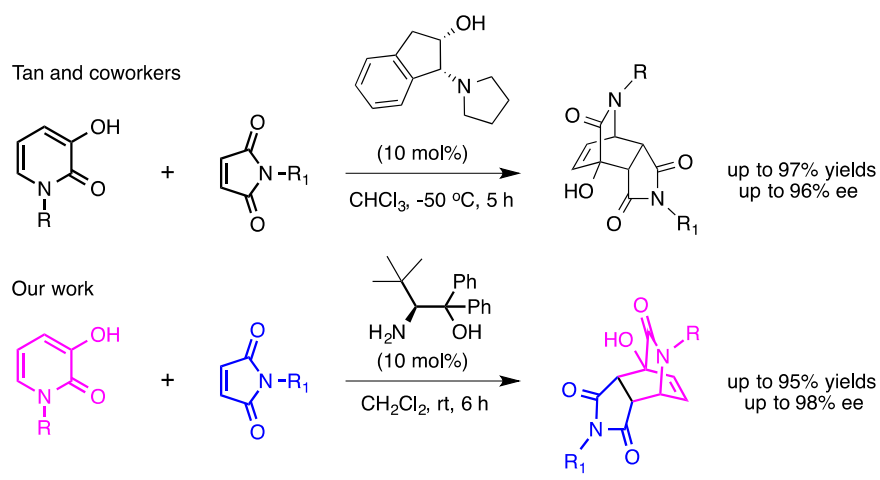

Scheme 2. Diels-Alder reaction of 3-hydroxy-2-pyridones with maleimides.

Recently we are developing the simple primary $\beta$-amino alcohols and their derivatives as a new class of organocatalysts, since they are easy to synthesize, stable on exposure to air, have the probability of introducing different functional groups and also alter the steric sites. ${ }^{10}$ And also, these catalysts could be used as inexpensive alternatives to other primary amino organocatalysts such as the chiral diamines and cinchona derived primary amines. Because of the presence of adjacently positioned bi-functional groups i.e, Brønsted acid and base sites, these could be used as iminium precursors and also as hydrogen bond source (Figure 1).

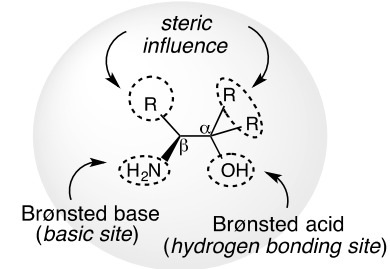

Figure 1. Functionality of $\beta$-amino alcohols.

In continuation of our interest to synthesize the different $\beta$ amino alcohols and examination of their general applicability in diverse organic transformations as chiral organocatalysts ${ }^{10}$ and due to the importance of chiral isoquinuclidines as synthetic intermediates, herein we desire to examine the catalytic efficiency of simple primary $\beta$-amino alcohols in DA reaction of 3-hydroxy-2-pyridones with maleimides. The reaction of

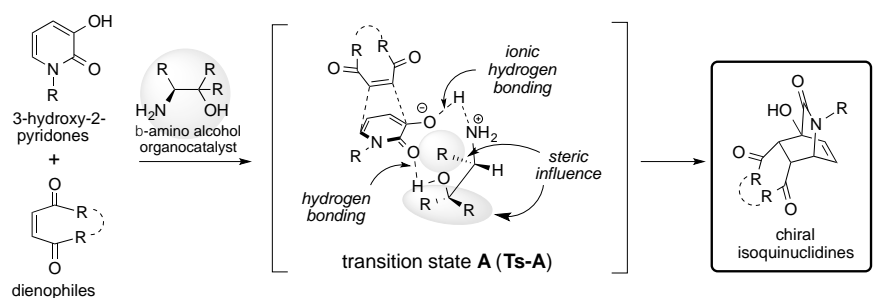

Scheme 3. Concept for asymmetry induction using $\beta$-amino alcohol organocatalyst.

3-hydroxy-2-pyridones as a diene with maleimides might be afforded the DA adducts through the transition state $\mathbf{T s - A}$, in which the diene could be fixed by the two hydrogen bonding interactions between the ammonium site on the ammonium alcohol intermediate and the hydroxyl group at 3-position on the 2-pyridones and between the hydroxyl group of ammonium alcohol intermediate and the carbonyl group at 2-position on the 2-pyridones, then dienophiles might react stereo selectively from the less steric interaction site of diene to provide the chiral isoquinuclidines (Scheme 3).

Herein, we describe the DA reaction of 3-hydroxy-2pyridones as dienes with $N$-substituted maleimides to afford the chiral isoquinuclidines in excellent chemical yields (up to 95\%) and enantioselectivity (up to $98 \%$ ee) using simple $\beta$-amino alcohols as Brønsted base organocatalysts (Scheme 2).

\section{Results and Discussion}

Primary amino alcohol catalysts $\mathbf{3 a - h}$, having aliphatic or aromatic substituents at the $\alpha$-and/or $\beta$-positions, respectively, were easily prepared through well-known Grignard reaction. ${ }^{10 f, 11}$ Whereas catalyst $\mathbf{3 i}$ was obtained by reduction of the corresponding $\alpha$-amino acid 2. ${ }^{10 \text { f, } 12}$ Moreover, both secondary and tertiary amino alcohols $\mathbf{4 a , b}$, were prepared by treating $\mathbf{3 d}$ with methyl iodide. ${ }^{10 f}$ Furthermore, tertiary amino alcohol $\mathbf{4 c}$ containing pyrrolidinyl ring system as an amino group at $\beta$ position was prepared by the reaction of $\mathbf{3 d}$ with 1,4dibromobutane. In addition, amino silyl ether 5 was obtained from 3d by masking the hydroxyl function with TMS (trimethylsilyl) group by treating with TMSOTf. ${ }^{10 \mathrm{~g}}$ Furthermore, $\alpha, \beta$-diamine 6 was prepared by the substitution reaction of the corresponding 3d with $\mathrm{NaN}_{3}$ followed by catalytic reduction using $\mathrm{Pd} / \mathrm{C}$ system. ${ }^{13}$ Primary amine catalyst $\mathbf{8}$ without hydroxyl group was prepared using the well-known method from the oxazolidinone $7^{10 \mathrm{f}}$ (Scheme 4$)$.
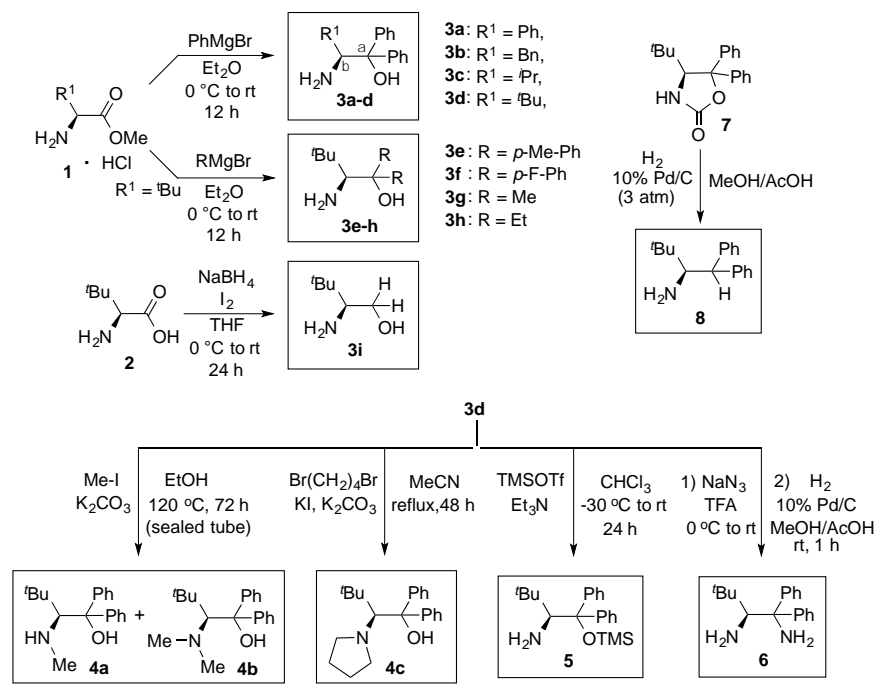

Scheme 4. Preparation of $\beta$-amino alcohols.

Initially, the catalytic activity of primary amino alcohol organocatalysts 3a-d comprising aromatic and aliphatic substituent groups at $\beta$-position and diphenyl groups at $\alpha$ position was examined in the DA reaction of 1-mesitylsulfonyl3-hydroxy-2-pyridone 9a with $\mathrm{N}$-phenylmaleimide $\mathbf{1 0 a}$ in $\mathrm{CH}_{2} \mathrm{Cl}_{2}$ at $-50{ }^{\circ} \mathrm{C}$ following the same reaction condition of Tan at all, ${ }^{9}$ and the results were presented (Table 1). All the used catalysts showed catalytic activities to afforded endo-DA adduct 11a in low to moderate chemical yields (31-60\%) but enantioselectivity (ee) was differ with substituent group at $\beta$-position. Thus, catalyst 3a bearing phenyl group at $\beta$-position afforded the DA adduct 11a at moderate chemical yield $(51 \%)$ and a quite poor enantioselectivity ( $8 \%$ ee) (entry 1). The bulkier catalyst $\mathbf{3 b}$ having benzyl group improved enantioselectivity to $25 \%$ ee, although the chemical yield was decreased (entry 2). Catalyst $\mathbf{3 c}$ 
containing iso-propyl group at $\beta$-position yield the DA adduct with $37 \% e e$ and $60 \%$ yield (entry 3 ). Best enantioselectivity ( $57 \%$ ee) was obtained by using catalyst $\mathbf{3 d}$ with tert-butyl group at $\beta$-position, although chemical yield was deeply decreased (entry 4).

Table 1. Diels-Alder reaction of 3-hydroxy-2-pyridone 9a with $\mathrm{N}$ phenylmaleimide 10a using catalysts 3a-d.

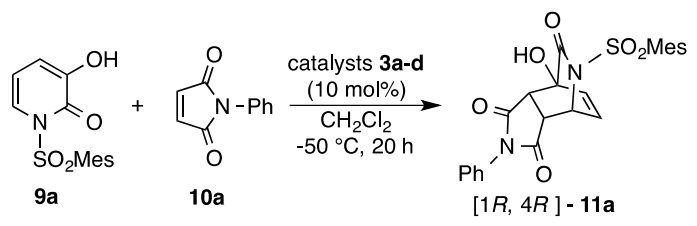

\begin{tabular}{cccc}
\hline entry & catalyst & ${\text { yield }(\%)^{\mathbf{a}}}^{\text {ee }(\%)^{\mathbf{b}}}$ \\
\hline $\mathbf{1}$ & 3a & $\mathbf{5 1}$ & $\mathbf{8}$ \\
$\mathbf{2}$ & 3b & 42 & 25 \\
3 & 3c & 60 & 37 \\
4 & 3d & 31 & 57 \\
\hline
\end{tabular}

a Isolated yields. ${ }^{\text {b }}$ Ee's were determined by chiral HPLC using chiralpak AS-H column

By using the superior catalyst 3d (10 mol\%), next we carried out the same reaction at room temperature with various dienes and dienophiles and results were presented (Table 2). Catalyst 3d furnished the endo-DA adduct 11a at room temperature with enhancement of chemical yield and enantioselectivity (42\%, 67\% ee) (entry 1). Considering of this result, next we examined the reaction of $9 \mathbf{a}$ with $N$-methylmaleimide $\mathbf{1 0 b}$ and $\mathrm{N}$ ethylmaleimide 10c, respectively (entries 2, 3). However, catalyst $\mathbf{3 d}$ did not yield the 11b with satisfactory results (entry 2). In contrast, fairly good enantioselectivity $(87 \%$ ee) was obtained when $N$-ethylmaleimide 10c was used, although chemical yield was low (entry 3). Furthermore, the reactions of $N$-tosyl-3hydroxy-2-pyridone 9b with $N$-substituted maleimides 10a-c were also carried out under the same reaction conditions (entries 4-6). But, $N$-phenyl-maleimide 10a and $N$-ethyl-maleimide 10c did not afford the corresponding endo-DA adducts 11d,f with satisfactorily results regarding both chemical yield and enantioselectivity (11d: 32\%, 35\% ee, 11f: 38\%, 65\% ee) (entries $4,6)$. On the other hand, excellent enantioselectivity ( $98 \%$ ee) and good chemical yield (61\%) was obtained from the reaction of 9b with 10b (entry 5). These results revealed that the use of 3hydroxy-2-pyridone $\mathbf{9 b}$ and $N$-methylmaleimide $\mathbf{1 0 b}$ in the presence of $\mathbf{3 d}$ was the best combinations for obtaining chiral DA adduct with the highest optical purity.

Table 2. Diels-Alder reaction of 3-hydroxy-2pyridones 9a,b with $\mathrm{N}$ substituted maleimides 10a-c using catalyst 3d.

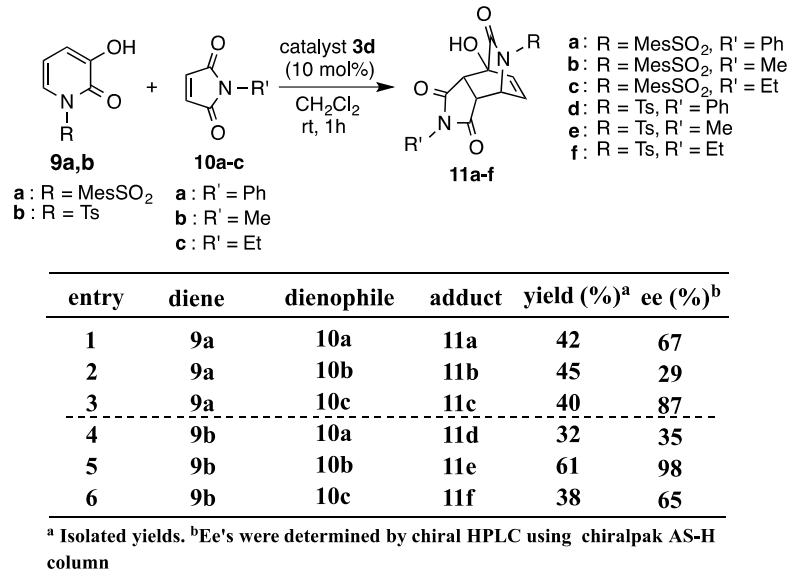

Next, we desire to study the electronic effect of the substituent group on the phenyl group at the $\alpha$-position of the best catalyst 3d. So that, the catalytic activities of $\beta$-amino alcohols 3e,f containing $p$-methyl (electron-donating) and $p$ fluoro (electron-withdrawing) groups on the phenyl groups at the $\alpha$-position were tested under the same reaction conditions (Table 3). Catalyst 3e afforded the corresponding DA adduct 11e in low chemical yield and moderate enantioselectivity $(37 \%, 60 \%$ ee) (entry 1). On the other hand, catalyst $\mathbf{3 f}$ brought about fairly good asymmetric induction ( $94 \%$ ee), but chemical yield was low $(38 \%)$ (entry 2). Furthermore, the catalytic activities of amino alcohols 3g-i containing dimethyl, diethyl and protons, respectively, at the $\alpha$-position were also examined under the same reaction conditions (entries 3-5). However, these catalysts afforded the DA adduct 11e in only low chemical yields and enantioselectivities (3g: 46\%, 32\% ee, 3h: 42\%, 40\% ee, 3i: $52 \%, 31 \%$ ee). Also, the catalytic abilities of secondary and tertiary amino alcohols $\mathbf{4 a}, \mathbf{b}$, respectively were also examined (entries 6,7). As expected, because of stronger basic property than primary amino alcohols, these catalysts provide the 11e in good chemical yields with excellent enantioselectivities (4a: $72 \%, 95 \%$ ee, 4b: $87 \%$, 97\% ee). However, they did not afford the better result than the primary amino alcohol catalyst $\mathbf{3 d}$ in respect of enantioselectivity $(98 \%$ ee). Furthermore, the catalytic activity of catalyst $\mathbf{4 c}$ containing pyrrolidinyl ring system also tested in this reaction (entry 8). However, only low enantioselectivity $(40 \%$ ee) was obtained, although chemical yield was considerably good (89\%). The catalytic activity of $\alpha, \beta$ diamine catalyst 5 was also examined (entry 9). We anticipated that one amino group might act as a base and another amino group might be used for hydrogen bonding with substrate but catalyst $\mathbf{5}$ yielded the DA adduct 11e with moderate chemical yield and enantioselectivity $(51 \%, 70 \% e e)$. Catalyst 6 bearing masked hydroxyl group with trimethylsilyl brought a great decrease in chemical yield $(31 \%)$, but enantioselectivity was moderate $(61 \%$ ee $)$ (entry 10$)$. We also examined the reaction using catalyst $\mathbf{8}$ with no substitution for the hydroxyl group at the $\alpha$-position (entry 11). Although the catalyst 8 afforded 11e in fairly good enantioselectivity (93\% ee), but chemical yield (30\%) was low in comparison with the results of catalyst 3d with hydroxyl group $(61 \%, 98 \%$ ee, entry 5 , Table 2$)$.

Table 3. Diels-Alder reaction of $9 b$ with $10 b$ using catalysts $3 \mathbf{e}-\mathbf{i}$, $4 a-c, 5,6,8$.

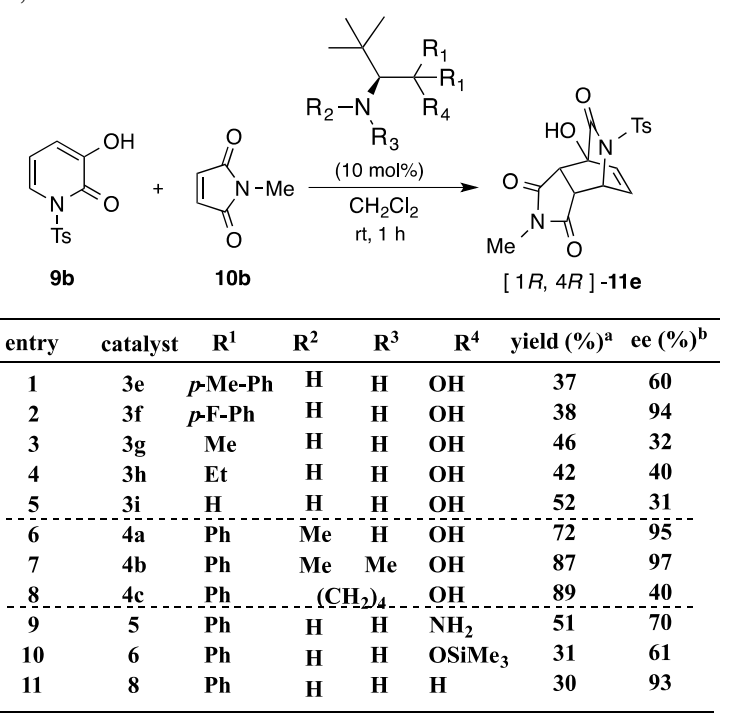

${ }^{a}$ Isolated yields. ${ }^{b}$ Ee's were determined by chiral HPLC using chiralpak AS-H column 
From the study of catalytic efficiency of all synthesized catalysts, we found that catalyst $\mathbf{3 d}$ was superior for this reaction to afford the best enantioselectivity ( $98 \%$ ee) with good chemical yield. In order to optimize the reaction conditions, next we examined the effects of the molar ratio of catalyst 3d, solvent, reaction temperature and reaction time (Table 4). The increase of catalytic loading of $\mathbf{3 d}$ to $20 \mathrm{~mol} \%$ did not increase the chemical yield and enantioselectivity $(62 \%, 98 \%$ ee) (entry 1$)$. On the other hand, the decrease of catalytic loading of $\mathbf{3 d}$ to 5 and 2.5 mol\% resulted in a decrease the chemical yields, but enantioselectivities were maintained at $98 \%$ ee and $96 \%$ ee, respectively (entries 2, 3). However, 1 and $0.5 \mathrm{~mol} \%$ of catalyst 3d brought about a great decrease in both chemical yields and enantioselectivities ( $1 \mathrm{~mol} \%$ : $24 \%, 69 \%$ ee, $0.5 \mathrm{~mol} \%$ : $17 \%, 37 \%$ ee) $($ entries 4,5$)$. When the reaction was carried out at $0{ }^{\circ} \mathrm{C}$, both chemical yield and enantioselectivity $(60 \%, 97 \%$ ee) were almost similar to the result at room temperature $(62,97 \%$ ee) (entry 6). The same reaction at $-20{ }^{\circ} \mathrm{C}$ and $-50{ }^{\circ} \mathrm{C}$ results the great decrease of the chemical yields $\left(-20^{\circ} \mathrm{C}: 46 \%,-50^{\circ} \mathrm{C}: 37 \%\right)$ and enantioselectivities were also slightly decreased $\left(-20^{\circ} \mathrm{C}: 94 \%\right.$ ee, $-50^{\circ} \mathrm{C}: 90 \%$ ee) (entries 7,8$)$. Using the best reaction condition (10 mol\% of catalyst $\mathbf{3 d}, \mathrm{rt}$ ), extending the reaction times from 1 to 3 and $6 \mathrm{~h}$ led to increase the chemical yields greatly with excellent enantioselectivity (entries 9, 10). Particularly, when the reaction was carried out for $6 \mathrm{~h}$, an excellent chemical yield and enantioselectivity was observed $(95 \%, 98 \%$ ee) (entry 10$)$. Next, we also examined the solvent effects on this reaction. Commonly used aprotic polar (DMF, MeCN) and protic ( $\mathrm{MeOH}, 2$-propanol) polar solvents were screened (entries 11-14). Unfortunately, no improvement was observed in enantioselectivity in these solvents with comparison the use of $\mathrm{CH}_{2} \mathrm{Cl}_{2}$.

Table 4. Optimized conditions for Diels-Alder reaction of $\mathbf{9 b}$ with 10b using catalyst $\mathbf{3 d}$.

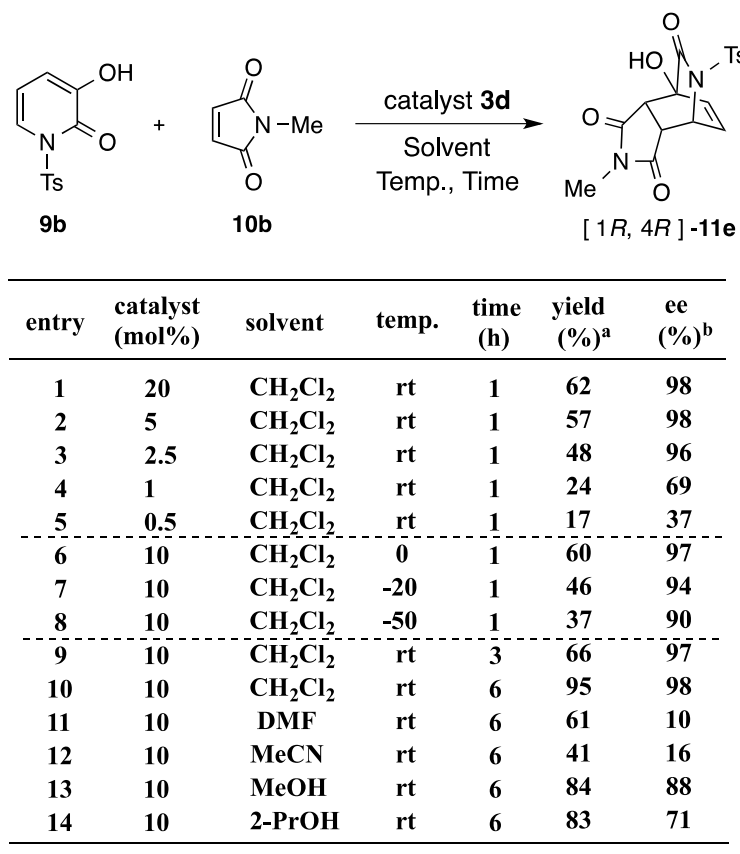

${ }^{a}$ Isolated yields. ${ }^{\text {bEe's were determined by chiral HPLC using chiralpak AS-H }}$ column

The absolute stereochemistry of the obtained DA adduct 11e was determined by the CD spectroscopy. Thus, the cotton effect pattern of the DA adduct 11e was showed to be same as that of $[1 R, 4 R]-11$ a whose structure was confirmed by X-ray diffraction. ${ }^{9}$ DA adduct 11a with known absolute configuration showed a positive Cotton effect at around $252.5 \mathrm{~nm}$ and a negative Cotton effect at around $235.5 \mathrm{~nm}$ in CD spectra. On the other hand, the new DA adduct 11e showed a positive Cotton effect at around $249.0 \mathrm{~nm}$ and a negative Cotton effect at around $232.5 \mathrm{~nm}$. From this experience, the absolute configuration of 11e was determined as $[1 R, 4 R]$ same as 11a (Scheme 5).
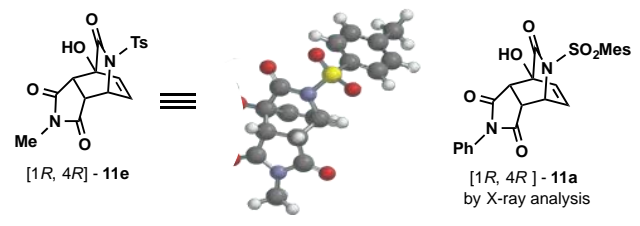

absolute configuration of $[1 R, 4 R]-11 e$ by $\mathrm{X}$-ray analysis

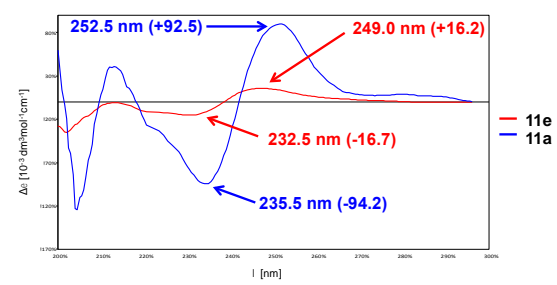

Scheme 5. Determination of absolute stereochemistry of DA adduct 11e using CD spectra.

Based on the observed enantiopurity (98\% ee) (entry 10 , Table 4) of the chiral endo-DA adduct 11e that was obtained from the reaction of $\mathbf{9 b}$ with $\mathbf{1 0 b}$, the model of the enantioselective reaction course was proposed as follows (Scheme 6). The endo DA adduct 11e might form through the transition state Ts-A form the reaction of reaction of $\mathbf{9 b}$ with 10b. In Ts-A, the pyridone $9 \mathbf{b}$ could be fixed by the two hydrogen bonding interactions between the ammonium site on the ammonium alcohol intermediate and the hydroxyl function at 3-position on 9b and between the hydroxyl group on the ammonium alcohol intermediate and the carbonyl group at 2position on 9b, and then maleimide $10 \mathrm{~b}$ might attack enantioselectively from the one reaction site of $\mathbf{9 b}$, which shows a less steric interaction between tert-butyl and phenyl groups on the ammonium alcohol intermediate and the dienophile 10b, although the reason is not clear.

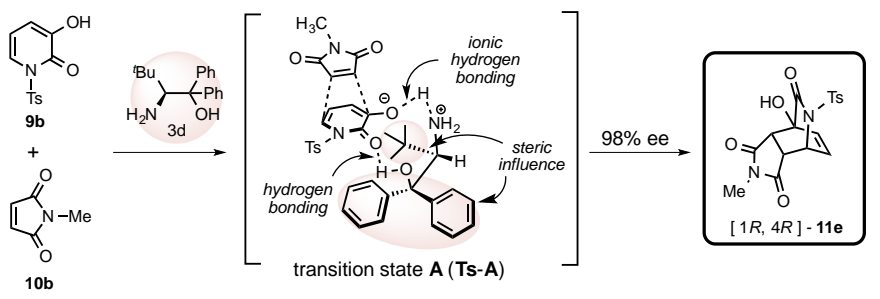

Scheme 6. Plausible reaction course.

\section{Conclusion}

In conclusion, simple optically active primary $\beta$-amino alcohol organocatalysts showed a dramatic asymmetric catalytic activity for affording chiral DA adducts with excellent chemical yields and enantioselectivities (up to $95 \%$ yield, up to $98 \%$ ee) in the DA reactions of 3-hydroxy-2-pyridones with $N$-substituted maleimides. In particular, catalyst 3d bearing tert-butyl group at $\beta$-position afforded the corresponding chiral endo-DA adduct 11e with fairly good chemical yield and an excellent enantioselectivity $(95 \%, 98 \%$ ee). These simple $\beta$-amino alcohol catalysts might be superior for practical use, because of these catalysts are stable in air and could be synthesized easily form inexpensive commercially available amino acids by means of well-known reactions in few steps. The enantioselective synthesis of DA adducts using 3-hydroxy-2-pyridones as dienes is challenging and important task because of the resulted DA 
adducts could be used as synthetic precursors for total synthesis of various biologically active scaffolds. Application of DA adducts in synthesis of biologically active molecules and mechanistic studies of these catalysts for this reaction are now in progress and results will be published in the due course.

\section{Acknowledgment}

This research is partially supported by the Adaptable \& Seamless Technology Transfer Program through Target-driven R\&D from Japan Science and Technology Agency, JST (AS231Z01382G).

\section{References and notes}

1. a) Dalko, P. I.; Moisan, L. Angew. Chem. Int. Ed. Engl. 2001, 41 , 3726-3748; b) List, B. Adv. Synth. and Cat. 2004, 346, 1021; c) Lopez, E. M.; Herrera, R. P.; Christmann, M. Nat. Prod. Rep. 2010, 27, 1138-1167; d) Atodiresei, I.; Vila, C.; Rueping M. ACS Catal. 2015, 5, 1972-1985.

2. For selective reviews of Diels-Alder reaction, see: a) Henri, B. Kagan B.; Riant, O. Chm. Rev. 1992. 92, 1007-1019; b) Corey, E. J. Angew. Chem. Int. Ed. 2002, 41, 1650-1667.

3. For application of Diels-Alder reaction in total synthesis, see: a) Nicolaou, K. C.; Snyder, S. A.; Montagnon, T.; Vassilikogiannakis, G. Angew. Chem. Int. Ed. 2002, 41, 1668-1698; b) Takao, K.; Munakata, R.; Tadano, K. Chem. Rev. 2005, 105, 4779-4807.

4. Dias, L. C.; Braz. J. Chem. Soc. 1997, 8, 289-332; b) Ishihara, J.; Nakadachi, S.; Watanabe, Y.; Hatakeyama, S. J. Org. Chem. 2015, 80, 2037-2041.

5. Few recently examples. a) Hatano, M.; Goto, Y.; Izumiseki, A.; Akakura, M.; Ishihara, K. J. Am. Chem. Soc. 2015, 137, 1347213475; b) Wang, Y.; Tu, M. S.; Yin, L.; Sun, M.; Shi, F. J. Org. Chem. 2015, 80, 3223-3232.

6. a) Kameda, Y.; Kawashima, K.; Takeuchi, M.; Ikeda, K.; Asano, N.; Matsui, K. Carbohydr Res. 1997, 300, 259-264; b) Takeuchi, M.; Takai, N.; Asano, N.; Kameda, Y.; Matsui, K. Chem Pharm Bull. 1990, 38, 1970-1972.

7. Javier, M. Chem. Rev. 2009, 109, 4398-4438.

$8 . \quad$ a) Kipassa, N. T.; Okamura, H.; Kina, K.; Hamada, T.; Iwagawa, T. Org. Lett. 2008, 10, 815-816; b) Posner, H. G.; Vinader, V.; Afarinkia, K. J. J. Org. Chem. 1992, 57, 4088-4097; c) Masato, H.; Hisao, M.; Reiko, F. Chem. Pharm. Bull. 2008, 56, 480-484; d) Bohm, M.; Lorthiois, E.; Meyyappan, M.; Vasella, A. Hel V. Chim. Acta. 2003, 86, 3787-3817.

9. Julian, Y. S.; Tan. C. H. J. Am. Chem. Soc. 2009, 131, 6904-6905.

10. a) Subba Reddy, U. V.; Chennapuram, M.; Seki, C.; Okuyama, Y.; Kwon, E.; Nakano, H. Eur. J. Org. Chem. 2016, 4124-4143; b) Kimura, J.; Subba Reddy, U. V.; Kohari, Y.; Seki, C.; Mawatari, Y.; Uwai, K.; Okuyama, Y.; Kwon, E.; Tokiwa, M.; Takeshita, M.; Iwasa, T.; Nakano, H. Eur. J. Org. Chem. 2016, 3728-3756; c) Nakano, H.; Kumagai, J.; Subba Reddy, U. V.; Seki, C.; Okuyama, Y.; Kwon, E. J. Syn. Org. Chem. 2016, 74, 720-731; d) Kumagai, J.; Otsuki, T.; Subba Reddy, U. V.; Kohari, Y.; Seki, C.; Uwai, K.; Okuyama, Y.; Kwon, E.; Tokiwa, M.; Takeshita, M.; Nakano, H. Tetrahedron: Asymmetry 2015, 26, 1423-1439; e) Otsuki, T. Kumagai, J.; Kohari, Y.; Okuyama, Y.; Kwon, E.; Seki, C.; Uwai, K.; Mawatari, Y.; Kobayashi, N.; Iwasa, T.; Tokiwa, M.; Takeshita, M.; Maeda, A.; Hashimoto, A.; Turuga, K.; Nakano, H. Eur. J. Org. Chem. 2015, 7292-7300; f) Kohari, Y.; Okuyama, Y.; Kwon, E.; Furuyama, T.; Kobayashi, N.; Otuki, T.; Kumagai, J.; Seki, C.; Uwai, K.; Dai, G.; Iwasa, T.; Nakano, H. J. Org. Chem. 2014, 79, 9500-9511; g) Sakuta, Y.; Kohari, Y.; Hutabarat, N. D. M. R.; Uwai, K.; Kwon, E.; Okuyama, Y.; Seki, C.; Matsuyama, H.; Takano, N.; Tokiwa, M.; Takeshita, M.; Nakano, H. Heterocycles 2012, 86, 1379-1389; h) Suttibut, C.; Kohari, Y.; Igarashi, K.; Nakano, H.; Hirama, M.; Seki, C.; Matsuyama, H.; Uwai, K.; Takano, N.; Okuyama, Y.; Osone, K.; Takeshita, M.; Kwon, E. Tetrahedron Lett. 2011, 52, 4745-4748; i) Nakano, H.; Osone, K.; Takeshita, M.; Kwon, E.; Seki, C.; Matsuyama, H.; Takano, N.; Kohari, Y. Chem. Comm. 2010, 46, 4827-4829.

11. Korkmaz, N.; Astley, D.; Astley. S. T. Turk. J. Chem. 2011, 35, 361-374.

12. Malkov, A. V.; Kabeshov, M. A.; Bella, M.; Kysilka, O.; Malyshev, D. A.; Pluhackova, K.; Kocovsky. P. Org. Lett. 2007, 9, 5473-5476.

13. Uraguchi, D.; Sakaki, S.; Ueki, Y.; Ito, T.; Ooi. T. Heterocycles 2008, 76, 1081-1085.
14. Spectral data for new compounds. (S)-(2-dimethylamino)-3,3Dimethyl-1,1-diphenylbutan-1-ol (4b): White solid, m.p. : 110-115 ${ }^{\circ} \mathrm{C} ;[\alpha]_{\mathrm{D}}{ }^{22}=-36.3\left(\mathrm{c} 0.22, \mathrm{CHCl}_{3}\right.$ ); IR (neat) $\mathrm{cm}^{-1}: 3626,3033$, $2900,1660,1447,1277,1050 ;{ }^{1} \mathrm{H}$ NMR $\left(\mathrm{CDCl}_{3}, 500 \mathrm{MHz}\right): \delta 7.58-$ $7.55(\mathrm{~m}, 5 \mathrm{H}), 7.24-7.20(\mathrm{~m} 3 \mathrm{H}), 7.10-7.07(\mathrm{~m}, 2 \mathrm{H}), 3.72(\mathrm{~s}, 1 \mathrm{H})$, $2.45(\mathrm{~s}, 6 \mathrm{H}), 0.85(\mathrm{~s}, 9 \mathrm{H}) ;{ }^{13} \mathrm{C} \mathrm{NMR}\left(\mathrm{CDCl}_{3}, 125 \mathrm{MHz}\right): \delta 148.6$, $128.3,127.9,127.5,127.3,126.6,126.5,126.1,125.8,125.6,125.4$, 76.8, 76.2, 40.9, 31.2, 27.8; FAB-MS m/z : $298[\mathrm{M}+\mathrm{H}]^{+}$; HRMS (FAB) calcd for $\mathrm{C}_{20} \mathrm{H}_{28} \mathrm{NO}: 298.2170[\mathrm{M}+\mathrm{H}]^{+}$, found : 298.2171 . (S)-3,3-dimethyl-1,1-diphenyl-2-(pyrrolidin-1-ly)buten-1-ol (4c): Colorless solid, m.p. : $120-124{ }^{\circ} \mathrm{C} ;[\alpha]_{\mathrm{D}}{ }^{23}=-28.0\left(\mathrm{c} 0.25, \mathrm{CHCl}_{3}\right)$; IR (neat) $\mathrm{cm}^{-1}: 3058,2955,2868,1735,1717,1597,1489,1364$, $1059 ;{ }^{1} \mathrm{H}$ NMR $\left(\mathrm{CDCl}_{3}, 500 \mathrm{MHz}\right): \delta$ 7.63-7.57 (m, 4H), 7.23-7.19 $(\mathrm{m}, 4 \mathrm{H}), 7.10-7.04(\mathrm{~m}, 2 \mathrm{H}), 3.98(\mathrm{~s}, 1 \mathrm{H}), 3.07-2.95(\mathrm{~m}, 4 \mathrm{H}), 1.35-$ $1.24(\mathrm{~m}, 4 \mathrm{H}), 0.88(\mathrm{~s}, 9 \mathrm{H}) ;{ }^{13} \mathrm{C} \mathrm{NMR}\left(\mathrm{CDCl}_{3}, 125 \mathrm{MHz}\right): \delta 128.9$, 128.5, 127.8, 127.7, 127.6, 127.4, 127.2, 125.9, 125.7, 125.5, 125.2, 52.1, 41.1, 31.4, 29.2, 26.7; EI-MS m/z : $323\left[\mathrm{MM}^{+}\right.$; HRMS (EI) calcd for $\mathrm{C}_{22} \mathrm{H}_{29} \mathrm{NO}: 323.2249[\mathrm{M}]^{+}$, found : 323.2241. (4R)-7hydroxy-9-(mesitylsulfonyl)-2-methyl-3a,4,7,7a-tetrahydro-1H4,7-(epiminomethano)isoindole-1,3,8(2H)-trione (11b): $\quad$ Pale yellow solid, m.p. : $180-182{ }^{\circ} \mathrm{C} ;[\alpha]_{\mathrm{D}}{ }^{20}=-2.7\left(\mathrm{c} 0.33, \mathrm{CHCl}_{3}\right)$; The $e e$ was determined by HPLC [DAICEL chiralpak AS-H column, hexane $/ 2$-propanol $=10 / 90$, flow rate: $0.2 \mathrm{~mL} / \mathrm{min}, \mathrm{t}_{\mathrm{r}}($ major $)=$ $47.23 \mathrm{~min}, \mathrm{t}_{\mathrm{r}}$ (minor) $\left.=116.84 \mathrm{~min}, e e=29 \%\right]$; IR (neat) $\mathrm{cm}^{-1}$ : $3329,2948,1779,1735,1689,1439,1347,1166,1106 ;{ }^{1} \mathrm{H}$ NMR $\left(\mathrm{CDCl}_{3}, 500 \mathrm{MHz}\right): \delta 6.98(\mathrm{~s}, 2 \mathrm{H}), 6.44(\mathrm{dd}, 1 \mathrm{H}, J=8.0,5.7 \mathrm{~Hz})$, $6.37(\mathrm{dd}, 1 \mathrm{H}, J=8.0,1.0 \mathrm{~Hz}), 5.81-5.79(\mathrm{~m}, 1 \mathrm{H}), 3.74(\mathrm{dd}, 1 \mathrm{H}, J=$ 8.1, $4.3 \mathrm{~Hz}), 3.11(\mathrm{~d}, 1 \mathrm{H}, J=7.9 \mathrm{~Hz}), 2.95(\mathrm{~s}, 3 \mathrm{H}), 2.57(\mathrm{~s}, 6 \mathrm{H})$, $2.29(\mathrm{~s}, 3 \mathrm{H}) ;{ }^{13} \mathrm{C}$ NMR $\left(\mathrm{CDCl}_{3}, 125 \mathrm{MHz}\right): \delta 173.5,173.2,170.7$, 144.9, 141.1, 137.3, 132.3, 131.6, 128.8, 51.3, 48.0, 44.8, 25.4, 22.7, 21.3; FAB-MS m/z : $405[\mathrm{M}+\mathrm{H}]^{+}$; HRMS (FAB) calcd for $\mathrm{C}_{19} \mathrm{H}_{21} \mathrm{~N}_{2} \mathrm{O}_{6} \mathrm{~S}: 405.1120[\mathrm{M}+\mathrm{H}]^{+}$, found : 405.1115. (4R)-7hydroxy-2-phenyl-9-tosyl-3a,4,7,7a-tetrahydro-1H-4,7-

(epiminomethano)isoindole-1,3,8(2H)-trione (11d): Pale yellow solid, m.p. : $190-191{ }^{\circ} \mathrm{C} ;[\alpha]_{\mathrm{D}}{ }^{20}=-6.7\left(\mathrm{c} 0.24, \mathrm{CHCl}_{3}\right)$; The ee was determined by HPLC [DAICEL chiralpak AD-H column, hexane/2propanol $=10 / 90$, flow rate: $0.2 \mathrm{~mL} / \mathrm{min}, \mathrm{t}_{\mathrm{r}}($ major $)=75.24 \mathrm{~min}$, $\mathrm{t}_{\mathrm{r}}($ minor $\left.)=178.13 \mathrm{~min}, e e=35 \%\right] ;$ IR (neat) $\mathrm{cm}^{-1}: 3449,3065$, $1781,1712,1449,1351,1240,1159,1107 ;{ }^{1} \mathrm{H}$ NMR $\left(\mathrm{CDCl}_{3}, 500\right.$ $\mathrm{MHz}): \delta 7.89(\mathrm{~d}, 2 \mathrm{H}, J=8.4 \mathrm{~Hz}), 7.46-7.38(\mathrm{~m}, 3 \mathrm{H}), 7.36-7.34(\mathrm{~m}$, $2 \mathrm{H}), 7.17-7.15(\mathrm{~m}, 2 \mathrm{H}), 6.48(\mathrm{dd}, 1 \mathrm{H}, J=7.9,5.9 \mathrm{~Hz}), 6.39(\mathrm{~d}, 1 \mathrm{H}$, $J=8.0 \mathrm{~Hz}), 5.85-5.82(\mathrm{~m}, 1 \mathrm{H}), 4.09(\mathrm{~s}, 1 \mathrm{H}), 3.74(\mathrm{dd}, 1 \mathrm{H}, J=8.3$, $4.3 \mathrm{~Hz}), 3.14(\mathrm{~d}, 1 \mathrm{H}, J=8.3 \mathrm{~Hz}), 2.57(\mathrm{~s}, 3 \mathrm{H}) ;{ }^{13} \mathrm{C} \mathrm{NMR}\left(\mathrm{CDCl}_{3}\right.$, $125 \mathrm{MHz}): \delta 172.5,169.7,146.4,136.8,134.5,131.1,130.0$, 129.4, 129.3, 129.2, 128.2, 126.2, 52.4, 47.3, 21.8; FAB-MS m/z : $439[\mathrm{M}+\mathrm{H}]^{+}$; HRMS (FAB) calcd for $\mathrm{C}_{22} \mathrm{H}_{18} \mathrm{~N}_{2} \mathrm{O}_{6} \mathrm{~S}: 439.0964[\mathrm{M}$ $+\mathrm{H}]^{+}$, found : 439.0970. (4R)-7-hydroxy-2-methyl-9-tosyl3a,4,7,7a-tetrahydro-1H-4,7-(epiminomethano)isoindole-

1,3,8(2H)-trione (11e): White solid, m.p : $225-227{ }^{\circ} \mathrm{C} ;[\alpha]_{\mathrm{D}}{ }^{20}=-20.7$ (c $0.34, \mathrm{CHCl}_{3}$ ); The ee was determined by HPLC [DAICEL chiralpak AD-H column, hexane/2-propanol $=10 / 90$, flow rate: 0.2 $\mathrm{mL} / \mathrm{min}, \mathrm{t}_{\mathrm{r}}($ mjor $)=49.36 \mathrm{~min}, \mathrm{t}_{\mathrm{r}}($ minor $\left.)=110.82 \mathrm{~min}, e e=98 \%\right]$; IR (neat) $\mathrm{cm}^{-1}: 3456,3072,1778,1709,1458,1360,1238,1154$, $1112 ;{ }^{1} \mathrm{H}$ NMR (DMSO-d $\left.6,500 \mathrm{MHz}\right): \delta 7.85(\mathrm{~d}, 2 \mathrm{H}, J=8.5 \mathrm{~Hz}$ ), $7.33(\mathrm{~d}, 2 \mathrm{H}, J=8.0 \mathrm{~Hz}), 6.34(\mathrm{dd}, 1 \mathrm{H}, J=6.0,2.0 \mathrm{~Hz}), 6.24(\mathrm{dd}$, $1 \mathrm{H}, J=7.5,1.0 \mathrm{~Hz}), 5.76(\mathrm{~m}, 1 \mathrm{H}), 3.58(\mathrm{dd}, 1 \mathrm{H}, J=4.5,3.5 \mathrm{~Hz})$, $3.01(\mathrm{~d}, 1 \mathrm{H}, J=8.5 \mathrm{~Hz}), 2.93(\mathrm{~s}, 3 \mathrm{H}), 2.43(\mathrm{~s}, 3 \mathrm{H}) ;{ }^{13} \mathrm{C}$ NMR (DMSO-d 6 , $125 \mathrm{MHz}$ ): $\delta$ 174. 7, 173.6, 170.6, 146.0, 136.6, 135.1, 130.3, 130.1, 128.2, 78.7, 52.1, 47.9, 42.0, 25.1, 21.6; FAB-MS $\mathrm{m} / \mathrm{z}: 377[\mathrm{M}+\mathrm{H}]^{+}$; HRMS (FAB) calcd for $\mathrm{C}_{17} \mathrm{H}_{16} \mathrm{~N}_{2} \mathrm{O}_{6} \mathrm{~S}: 377.0807$ $[\mathrm{M}+\mathrm{H}]^{+}$, found : 377.0813. (4R)-2-ethyl-7-hydroxy-9-tosyl3a,4,7,7a-tetrahydro-1H-4,7-(epiminomethano)isoindole -

1,3,8(2H)-trione (11f): Colorless solid, m.p. : $201-203{ }^{\circ} \mathrm{C} ;[\alpha]_{\mathrm{D}}{ }^{20}=$ -8.7 (c $0.35, \mathrm{CHCl}_{3}$ ); The $e e$ was determined by HPLC [DAICEL chiralpak AD-H column, hexane/2-propanol $=10 / 90$, flow rate: 0.2 $\mathrm{mL} / \mathrm{min}, \mathrm{t}_{\mathrm{r}}($ major $)=43.25 \mathrm{~min}, \mathrm{t}_{\mathrm{r}}($ minor $\left.)=11.73 \mathrm{~min}, e e=65 \%\right]$; IR (neat) $\mathrm{cm}^{-1}: 3445,2938,1731,1638,1596,1405,1344,1227$, 1099,$976 ;{ }^{1} \mathrm{H} \mathrm{NMR}\left(\mathrm{CDCl}_{3}, 500 \mathrm{MHz}\right): \delta 7.86(\mathrm{~d}, 2 \mathrm{H}, J=8.4 \mathrm{~Hz})$, $7.33(\mathrm{~d}, 2 \mathrm{H}, J=8.0 \mathrm{~Hz}), 6.34(\mathrm{dd}, 1 \mathrm{H}, J=8.0,5.9 \mathrm{~Hz}), 6.24(\mathrm{~d}, 1 \mathrm{H}$, $J=7.0 \mathrm{~Hz}), 5.75-5.73(\mathrm{~m}, 1 \mathrm{H}), 4.06(\mathrm{~s}, 1 \mathrm{H}), 3.54(\mathrm{dd}, 1 \mathrm{H}, J=8.0$, $4.2 \mathrm{~Hz}), 3.48(\mathrm{dd}, 1 \mathrm{H}, J=14.3,7.1 \mathrm{~Hz}), 2.96(\mathrm{~d}, 1 \mathrm{H}, J=8.2 \mathrm{~Hz})$, $2.43(\mathrm{~s}, 3 \mathrm{H}), 1.07(\mathrm{t}, 3 \mathrm{H}, J=7.2 \mathrm{~Hz}) ;{ }^{13} \mathrm{C} \mathrm{NMR}\left(\mathrm{CDCl}_{3}, 125 \mathrm{MHz}\right)$ : $\delta 173.5,173.2,170.7,146.3,136.6,134.6,130.0,129.3,129.2$, 128.9, 128.2, 77.7, 52.3, 47.3, 43.9, 34.3, 21.9; FAB-MS m/z : 391 $[\mathrm{M}+\mathrm{H}]^{+}$; HRMS (FAB) calcd for $\mathrm{C}_{18} \mathrm{H}_{19} \mathrm{~N}_{2} \mathrm{O}_{6} \mathrm{~S}: 391.0964[\mathrm{M}+$ $\mathrm{H}]^{+}$, found : 396.0963 . 


\section{Graphical Abstract}

Simple primary $\beta$-amino alcohol catalyzed enantioselective Diels-Alder reaction of 3-

Leave this area blank for abstract info. hydroxy-2-pyridones

Toshihisa Takahashi, U. V. Subba Reddy, Yoshihito Kohari, Chigusa Seki, Taniyuki Furuyama, Nagao

Kobayashi, Yuko Okuyama, Eunsang Kwon, Koji Uwai, Michio Tokiwa, Mitsuhiro Takeshita, Hiroto Nakano*
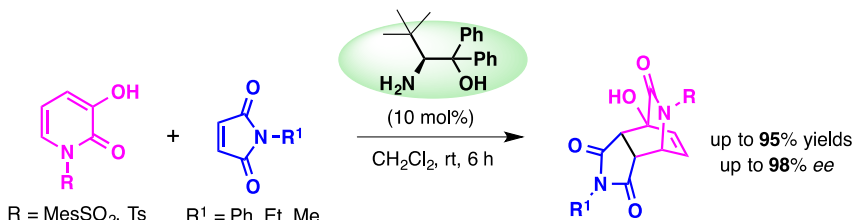

$\mathrm{R}=\mathrm{MesSO}_{2}$, Ts $\quad \mathrm{R}^{1}=\mathrm{Ph}, \mathrm{Et}, \mathrm{Me}$

$\mathbf{R}^{i^{N}}$ 